\title{
PETR PLECHÁČ
}

Versification and Authorship Attribution 
This PDF includes a chapter from the following book:

Versification and Authorship Attribution

(C) Petr Plecháč, 2021

\section{Versification Features}

Petr Plecháč

Institute of Czech Literature, Czech Academy of Sciences

e-mail: plechac@ucl.cas.cz

This work is licensed under a Creative Commons Attribution License

(http://creativecommons.org/licenses/by/4.0), which permits unrestricted use, distribution, and reproduction in any medium, provided the original author and source are credited.

https://doi.org/10.14712/9788024648903.3 


\section{Versification Features}

\subsection{Rhythm}

Since the time of Russian formalism, verse studies have distinguished between a poem's metre (i.e. the abstract pattern of each line) and its rhythm (i.e. the realisation of that metre through particular phonetic units). The relationship between strong ( $S$ ) and weak (W) metrical positions and particular phonetic qualities is usually not predetermined but rather stochastic. Precisely the same metre may, thus, be achieved in very different ways in particular lines. As an example, we may consider the opening quatrain of the first canto of Karel Hynek Mácha's Máj, a well-known Czech narrative poem. All of the lines are written in accentual-syllabic iambic tetrameter with a strong ending (S) but the rhythmic realisation through stressed ("1") and unstressed ("0") syllables is different in each line:

\begin{tabular}{|c|c|}
\hline \multirow{3}{*}{$\begin{array}{l}\text { rhythm: } \\
\text { metre: }\end{array}$} & Byl pozdní večer - první máj — \\
\hline & $\begin{array}{lllll}0 & 1 & 0 & 1 & 0\end{array}$ \\
\hline & 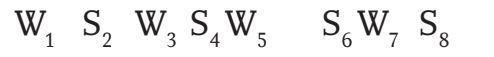 \\
\hline \multirow{3}{*}{$\begin{array}{l}\text { rhythm: } \\
\text { metre: }\end{array}$} & večerní máj - byl lásky čas. \\
\hline & $\begin{array}{llll}0 & 1 & 0 & 1\end{array}$ \\
\hline & $\mathrm{W}_{1} \mathrm{~S}_{2} \mathrm{~W}_{3} \mathrm{~S}_{4} \quad \mathrm{~W}_{5} \mathrm{~S}_{6} \mathrm{~W}_{7} \mathrm{~S}_{8}$ \\
\hline \multirow{4}{*}{$\begin{array}{l}\text { rhythm: } \\
\text { metre: }\end{array}$} & Hrdliččin zval ku lásce hlas, \\
\hline & $\begin{array}{llllllll}1 & 0 & 0 & 1 & 1 & 0 & 0 & 1\end{array}$ \\
\hline & $\mathrm{W}_{1} \mathrm{~S}_{2} \mathrm{~W}_{3} \quad \mathrm{~S}_{4} \quad \mathrm{~W}_{5} \mathrm{~S}_{6} \mathrm{~W}_{7} \mathrm{~S}_{8}$ \\
\hline & kde borový zaváněl háj. \\
\hline thm: & $0 \quad 10010001$ \\
\hline & $\mathrm{W}_{1} \mathrm{~S}_{2} \mathrm{~W}_{3} \mathrm{~S}_{4} \mathrm{~W}_{5} \mathrm{~S}_{6} \mathrm{~W}_{7} \mathrm{~S}_{8}$ \\
\hline
\end{tabular}


It is widely accepted that the distribution of rhythmic patterns is not random in the works of a given author. Rather, it is an important part of their individual style. While the choice of metre is often based on general conventions with some metres reserved, for example, for a particular genre, the overall way that it is achieved (rhythmic style) may be applied as a mark of authorship.

There are two main methods of capturing rhythmic style in continental European verse studies, and both of them originate in the Russian tradition. They are (1) determining a rhythmic profile and (2) measuring the frequencies of rhythmic types. ${ }^{8}$

\subsubsection{Rhythmic Profile}

A rhythmic profile is a vector that tracks the frequency of stressed syllables in particular metrical positions. As an illustration, FIG. 2.1 presents the rhythmic profiles of all lines of iambic tetrameter with a strong ending in (1) Máj, (2) other works by Karel Hynek Mácha and (3)-(5) three books of poetry by a later author, Josef Václav Sládek.

FIG. 2.1 captures some important differences between the rhythmic styles of the two authors: 9

(1) The initial $W_{1}$-position is stressed significantly more often in both Mácha samples than it is in Sládek's works.

(2) The $\mathrm{S}_{2}$-position is stressed significantly less often in both Mácha samples than it is in Sládek's works.

(3) The line-ending $\mathrm{S}_{8}$-position is stressed significantly more often in both Mácha samples than it is in Sládek's works.

(4) The $\mathrm{W}_{3}$-position and $\mathrm{W}_{5}$-position tend to be stressed slightly more often in both Mácha samples than they are in Sládek's works.

One disadvantage of the rhythmic profile method is that it completely disregards the context of particular syllables (cf. Dobritsyn 2016). FIG. 2.1 provides no information, for example, about what share of the approximately $13 \%$ of stressed syllables in the $\mathrm{W}_{5}$-position appear in monosyllabic words:

8 These features are also known respectively as a stress profile and rhythmic forms.

9 For a thorough analysis of these differences, see, e.g. Červenka 1998; Červenka and Sgallová 1978; Jirát 1931-1932; Jakobson 1938/1995. 


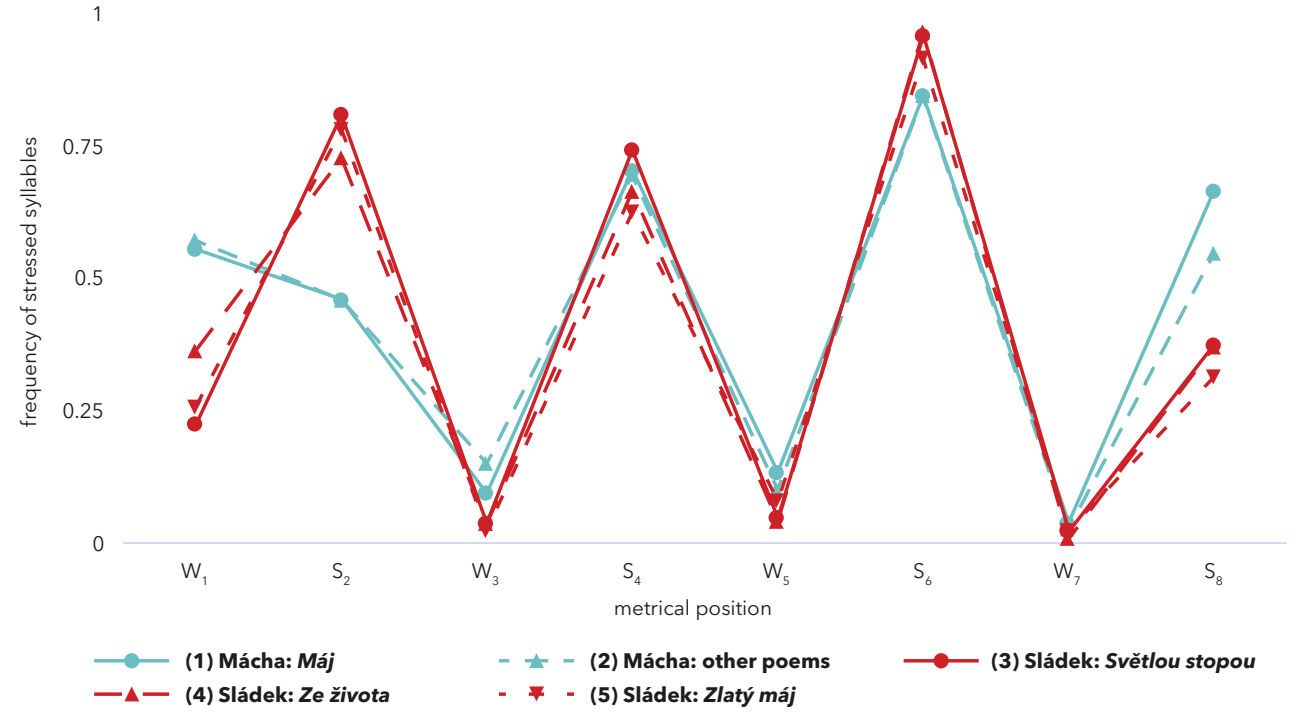

FIG. 2.1: Rhythmic profiles of all lines of iambic tetrameter with a strong ending in (1) Máj, (2) other works by Karel Hynek Mácha and (3)-(5) three books of poetry by a later author, Josef Václav Sládek.

„Kde Vilém můj?“ „Viz“, plavec k ní

rhythm: $\quad \begin{array}{llllllll}0 & 1 & 0 & 1 & 1 & 1 & 0 & 0\end{array}$

metre: $\quad \mathrm{W}_{1} \mathrm{~S}_{2} \mathrm{~W}_{3} \quad \mathrm{~S}_{4} \quad \mathrm{~W}_{5} \quad \mathrm{~S}_{6} \mathrm{~W}_{7} \mathrm{~S}_{8}$

(K. H. Mácha)

And, of course, we face the same question about the remaining share contained in polysyllabic words:

Kde borový zaváněl háj

rhythm: $\quad 0 \quad 1001001$

metre: $\quad \mathrm{W}_{1} \mathrm{~S}_{2} \mathrm{~W}_{3} \mathrm{~S}_{4} \mathrm{~W}_{5} \mathrm{~S}_{6} \mathrm{~W}_{7} \mathrm{~S}_{8}$

(K. H. Mácha)

The most crucial problem, however, relates to so-called extrametrical syllables, i.e. cases where more than one syllable corresponds to a single metrical position. In Czech accentual-syllabic verse, these instances are rather rare: 
Přistoupí strážce a lampy zář,

rhythm: $\quad \begin{array}{lllllllllll} & 0 & 0 & 1 & 0 & 0 & 1 & 0 & 1\end{array}$

metre: $\left.\quad \mathrm{W}_{0} \mathrm{~S}_{1} \mathrm{~W}_{1} \mathrm{~S}_{2} \mathrm{~L}_{2}\right\lrcorner \mathrm{S}_{3} \mathrm{~W}_{3} \mathrm{~S}_{4}$

(K. H. Mácha)

They are, however, very common in other syllabic accentual traditions. In English, for instance, we find:

Those trackless deeps where many a weary sail

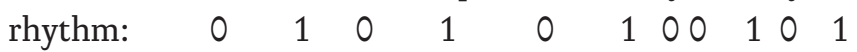

metre: $\quad W_{0} \quad \mathrm{~S}_{1} \mathrm{~W}_{1} \quad \mathrm{~S}_{2} \quad \mathrm{~W}_{2} \quad \mathrm{~S}_{3} \mathrm{~L}_{3} \mathrm{~W}_{4} \mathrm{~S}_{4} \mathrm{~W}_{4} \mathrm{~S}_{5}$

(P. B. Shelley)

The same holds true for metrical positions that are left blank (ø), or what are sometimes called "headless lines":

Stay, the King hath thrown his warder down

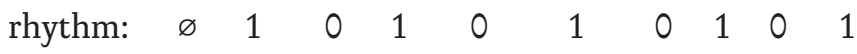

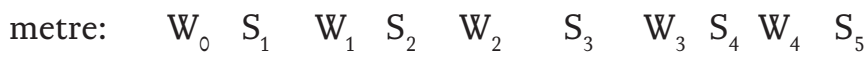

(W. Shakespeare)

Since rhythmic profiling assumes metrical position to be a binary variable (achieved through either a stressed or unstressed syllable), it has no way to reflect these situations.

\subsubsection{Rhythmic Type}

The rhythmic type of a verse line describes the entire bit string that captures its rhythm. According to this approach, a poetic text can be represented based on the frequencies of its rhythmic types. TAB. 2.1 gives an example of one such representation. This is a 47-dimensional vector for the entire text of Mácha's Máj.

The rhythmic type method has no difficulty in resolving cases which the rhythmic profile approach cannot handle. Both extrametrical syllables (ranks 31-47, line "Přistoupí strážce...”) and headless lines (ranks 31-47, line "Znovu v mdlobách...”) are processed easily. Moreover, since this method does not focus on particular metrical positions but rather on entire lines, it can also be applied within systems where the 


\begin{tabular}{|c|c|c|c|c|}
\hline$\overline{\text { rank }}$ & rhythmic type & relative frequency & absolute frequency & example \\
\hline 1 & 10010101 & 0.2305 & 80 & Večerní máj - byl lásky čas \\
\hline 2 & 01010101 & 0.1671 & 58 & Byl pozdní večer - první máj \\
\hline 3 & 10010100 & 0.0922 & 32 & Modré se mlhy houpají \\
\hline 4 & 01010100 & 0.0605 & 21 & Já zatím hrob mu vyryji \\
\hline $5-6$ & 01000100 & 0.0519 & 18 & Vzdy zeleněji prosvítá \\
\hline $5-6$ & 10100101 & 0.0519 & 18 & Břeh je objímal kol a kol \\
\hline 7 & 01000101 & 0.0432 & 15 & Tam při jezeru vížka ční \\
\hline 8 & 01001001 & 0.0288 & 10 & Kde borový zaváněl háj \\
\hline $9-10$ & 10011001 & 0.0230 & 8 & Hrdliččin zval ku lásce hlas \\
\hline 9-10 & 10100100 & 0.0230 & 8 & Dále zeleně zakvítá \\
\hline $31-47$ & 100100101 & 0.0029 & 1 & Přistoupí strážce a lampy záŕ \\
\hline $31-47$ & 1010100 & 0.0029 & 1 & Znovu v mdlobách umírá \\
\hline
\end{tabular}

TAB. 2.1: Rhythmic types of lines of iambic tetrameter with a strong ending in Karel Hynek Mácha's Máj.

number of positions varies (accentual verse) or where it makes no sense to distinguish them (free verse). On the other hand, the rhythmic type approach may produce rather sparse data. Some author-specific substrings may also end up being divided among a large number of less common types.

\subsubsection{Rhythmic N-Grams}

Given the limitations outlined in the previous sections, this book proposes using a method inspired by Forstall, Jacobson and Scheirer (2011) that charts a middle course. This method involves measuring the frequencies not of entire bit strings but their substrings. The latter are described here as rhythmic n-grams.

From a verse line with $k$ metrical positions, I extract all possible substrings that are of length $n$ and start at the $i$-th position $(i \in\{1,2,3, \ldots, k-n+1\})$. I then measure the frequencies of their rhythmic realisations. This can be illustrated by looking at the frequencies of rhythmic bigrams in Mácha's Máj (TAB. 2.2).

To capture the range of rhythmic variations as fully as possible, I represent the samples from my experiments with syllabic (Spanish) and accentual-syllabic (Czech) data through a combination of the frequencies of rhythmic 2-, 3- and 4-grams. In the case of the purely accentual (German) samples, I rely on the rhythmic type method for the reasons given in Section 2.1.2. 


\begin{tabular}{lcccccccccc}
\hline & \multicolumn{10}{c}{ Rhythmic realisations } \\
\cline { 2 - 11 } & $\mathbf{0 0}$ & $\mathbf{0 1}$ & $\mathbf{1 0}$ & $\mathbf{1 1}$ & $\mathbf{0 0 0}$ & $\mathbf{0 0 1}$ & $\mathbf{0 1 1}$ & $\mathbf{1 0 1}$ & $\mathbf{1 0 0}$ & $\varnothing \mathbf{1}$ \\
\hline $\mathbf{W}_{\mathbf{0}} \mathbf{S}_{\mathbf{1}}$ & & 0.4092 & 0.5533 & 0.0346 & & & & & & 0.0029 \\
$\mathbf{S}_{\mathbf{1}} \mathbf{W}_{\mathbf{1}}$ & 0.4611 & 0.0893 & 0.4467 & & & 0.0029 & & & & \\
$\mathbf{W}_{\mathbf{1}} \mathbf{S}_{\mathbf{2}}$ & 0.2017 & 0.7061 & 0.0836 & 0.0058 & & & 0.0029 & & & \\
$\mathbf{S}_{\mathbf{2}} \mathbf{W}_{\mathbf{2}}$ & 0.2104 & 0.0749 & 0.6340 & 0.0490 & & & & 0.0029 & 0.0029 & \\
$\mathbf{W}_{\mathbf{2}} \mathbf{S}_{\mathbf{3}}$ & 0.0432 & 0.8012 & 0.1066 & 0.017 & & 0.0029 & 0.0029 & & & \\
$\mathbf{S}_{\mathbf{3}} \mathbf{W}_{\mathbf{3}}$ & 0.1239 & 0.0259 & 0.8242 & 0.0086 & & & & 0.0029 & 0.0144 & \\
$\mathbf{W}_{\mathbf{3}} \mathbf{S}_{\mathbf{4}}$ & 0.3083 & 0.6397 & 0.0345 & & 0.0058 & 0.0086 & 0.0029 & & & \\
\hline
\end{tabular}

TAB. 2.2: Rhythmic bigrams of lines of iambic tetrameter with a strong ending in Karel Hynek Mácha's Máj.

\subsection{Rhyme}

The peculiarities of rhyme are also generally recognised as author-specific. For my purposes, rhymes are represented as unordered pairs of the following features of both rhyming words:

(1) morphological features (for the Czech data, this refers to the first position of the Positional $\operatorname{Tag}^{10}$ (=part of speech); for the German and Spanish data, this is the entire tag produced by the stochastic tagger TreeTagger ${ }^{11}$ ),

(2) word length measured by the number of syllables,

(3) number of syllables after the stressed syllable,

(4) final syllable coda,

(5) final syllable nucleus,

(6) onset of the final syllable + coda of the penultimate syllable (weak rhymes only) and

(7) nucleus of the penultimate syllable (weak rhymes only).

TAB. 2.3 breaks down the rhymes found in Johann Wolfgang Goethe's "Wandrers Nachtlied II" according to this schema: ${ }^{12}$

Über allen Gipfeln

Ist Ruh', In allen Wipfeln

10 See Hajič 2004.

11 See <http://www.cis.uni-muenchen.de/ schmid/tools/TreeTagger/>.

12 The International Phonetic Alphabet is used to represent sounds throughout this book. 


\begin{tabular}{|c|c|c|c|c|}
\hline & Gipfeln : Wipfeln & Ruh : du & Hauch : auch & Walde : balde \\
\hline (1) & $\{N N, N N\}$ & $\{N N, P P E R\}$ & $\{N N, A D V\}$ & $\{N N, A D V\}$ \\
\hline (2) & $\{2,2\}$ & $\{1,1\}$ & $\{1,1\}$ & $\{2,2\}$ \\
\hline (3) & $\{1,1\}$ & $\{0,0\}$ & $\{0,0\}$ & $\{1,1\}$ \\
\hline (4) & $\{\ln , \ln \}$ & $\{\varnothing, \varnothing\}$ & $\{x, x\}$ & $\{\varnothing, \varnothing\}$ \\
\hline (5) & $\{\partial, \partial\}$ & $\{u:, u:\}$ & $\{a v, a v\}$ & $\{\partial, \partial\}$ \\
\hline (6) & $\{p f, p f\}$ & - & - & $\{|d| d\}$, \\
\hline (7) & $\{\mathrm{I}, \mathrm{I}\}$ & - & - & $\{a, a\}$ \\
\hline
\end{tabular}

TAB. 2.3: Rhymes contained in Johann Wolfgang Goethe's "Wandrers Nachtlied II".

\author{
Spürest du \\ Kaum einen Hauch; \\ Die Vögelein schweigen im Walde. \\ Warte nur, balde \\ Ruhest du auch.
}

The samples in my experiments are represented by the relative frequencies of these pairs within the relevant rhyme type (strong/weak ending).

\title{
2.3 Euphony
}

Finally, preferences for the accumulation of certain sounds or sound clusters within a short section of text (line, stanza) may also be understood as somehow author-specific. I describe this aspect of versification as euphony. Although there have been several attempts to capture phenomena of this kind through inferential statistics (e.g. Čech, Popescu and Altmann 2011), these approaches have always focused on only one subtype (e.g. the repetition of a sound within a single line). In my experiments in the next chapter, I use a very simple approximation of these phenomena: the samples are represented according to the frequencies of particular sounds. 